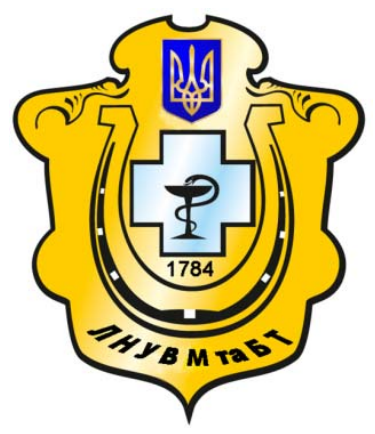

Науковий вісник Львівського національного університету ветеринарної медицини та біотехнологій імені С.3. Гжицького

Scientific Messenger of Lviv National University of Veterinary Medicine and Biotechnologies named after S.Z. Gzhytskyj

doi:10.15421/nvlvet6922

ISSN 2413-5550 print

ISSN 2518-1327 online

http://nvlvet.com.ua/

УДК 330.13:631.115.75:634.1/.7

\title{
Підвищення економічної ефективності збуту суниці садової на ринок переробки
}

\author{
Т.Г Пенцак, А.В. Галяс \\ tpentsak@ukr.net
}

\begin{abstract}
Львівський національний університет ветеринарної медицини та біотехнологій імені С.3. Гжицького, вул. Пекарська, 50, м. Львів, 79010, Украӥна
\end{abstract}

Ягіднищтво в сучасних умовах в основному зосереджується на застосуванні новітніх технологій вирощування та просування ягідної продукції задля збільшення рентабельності. В Україні виробники суниці садової (полуниці) при плануванні нових посадок в більшості концентрують свою увагу на збуті на свіжий ринок, а ие оптові ринки та супермаркети. Проте, більшість з них не беруть до уваги такий вагомий сегмент ринку як переробку, керуючись судженням, щзо на переробку слід продавати тільки неякісну та другосортну ягоду. В даній статті проведено аналіз сучасного стану збуту сунииі садової як сільськогосподарськими підприємствами різних форм власності так і особистими селянськими господарствами (ОСГ) на ринок переробки, а саме на подальшу заморозку. Описано шляхи підвищення економічної ефективності збуту суниці садовоі на цей ринок через дотримання виробниками умов вирощування, збирання, доробки та транспортування ягоди до покупия. Надано практичні рекомендаиії виробникам сунииі щзодо методів вирощування Проаналізовано можливості збуту ягід дрібними виробниками через сільськогосподарські обслуговуючі кооперативи.

Доведено, щуо у виробників суничі садової Західних областей Украӥни окрім збуту на свіжий ринок є можливості продавати на ринок переробки, а саме заморозки, проте вона повинна відповідати якісним вимогам. В свою чергу якість ягоди закладається починаючи від посадки і закінчуючи правильним періодом збору та логістикою з поля до камер охолодження.

Ключові слова: економічна ефективність, суничя садова (суниия), збут, ринок переробки, заморозка, сільське господарство, реалізачія, підприємство, кооперативи.

\section{Повышение экономической эффективности сбыта клубники садовой на рынок переработки}

\author{
Т.Г. Пенцак, А.В. Галяс \\ tpentsak@ukr.net
}

Львовский национальный университет ветеринарной медицины и биотехнологий имени С.3. Гжицкого, ул. Пекарская, 50, г. Львов, 79010, Украина

\begin{abstract}
Ягодоводство в современных условиях в основном сосредотачивается на применении новейших технологий выращивания и продвижения ягодной продукции для увеличения рентабельности. В Украине производители земляники садовой (клубники) при планировании новых посадок в большинстве кониентрируют свое внилание на сбыте на свежий рынок, а это оптовые рынки и супермаркеты. Однако, большинство из них не принимают во внимание такой весомый сегмент рынка как переработку, руководствуясь суждением, что на переработку следует продавать только некачественную и второсортную ягоду. В данной статье проведен анализ современного состояния сбыта земляники садовой как сельскохозяйственными предприятиями различных форм собственности так и личными крестьянскими хозяйствами (ОСГ) на рынок переработки, а именно на дальнейшую заморозку. Описаны пути повышения экономической эффективности сбыта земляники садовой на этот рынок через соблюдение производителями условий выращивания, сбора, доработки и транспортировки ягоды к покупателю. Даны практические рекомендации производителям земляники о методах вырашивания Проана-
\end{abstract}

Citation:

Pentsak, T., Halyas, A. (2016). Increase economic efficiency of marketing of the strawberry into processing market. Scientific Messenger LNUVMBT named after S.Z. Gzhytskyj, 18, 2(69), 113-117. 
лизированы возможности сбыта ягод мелкими производителями через сельскохозяйственные обслуживающие кооператиBbl.

Доказано, что у производителей земляники садовой Западных областей Украины кроме сбыта на свежий рынок есть возможности продавать на рынок переработки, а именно заморозки, однако она должна соответствовать качественным требованиям. В свою очередь качество ягоды закладывается начиная от посадки и заканчивая правильным периодом сбора и логистикой с поля в камеры охлаждения.

Ключевые слова: экономическая эффективность, земляника садовая (клубника), сбыт, рынок переработки, заморозка, сельское хозяйство, реализация, предприятие, кооперативыл.

\title{
Increase economic efficiency of marketing of the strawberry into processing market
}

\author{
T. Pentsak, A. Halyas \\ tpentsak@ukr.net

\begin{abstract}
Lviv National University of Veterinary Medicine and Biotechnologies named after S.Z. Gzhytskyi, Pekarska Str., 50, Lviv, 79010, Ukraine
\end{abstract}

In current conditions berries production is concentrated on implementation of modern technologies of production and marketing of berries products for increasing of profitability. Planning activities Ukrainian strawberry producers are mainly focused on selling to fresh market through wholesale markets and supermarkets. In the same time majority of them do not take into consideration opportunities given by industrial market. They are ruled by judgment that industrial market consume only low quality, second sort berries. In the article conducted analysis of current situation with strawberry sale by agricultural enterprises and householders for processing, in particular for freezing. Described ways of strawberry sale economic effectiveness increasing through respecting of production, handling and harvesting technologies by producers. Analyzed opportunities to sell berries by small producers through agricultural services cooperatives.

Proved that in strawberry producers from Western Ukraine there is opportunity to sell strawberry to industrial market including frozen apart fresh one. But strawberry should correspond to quality requirement. In the same time the quality of berries begin from plantation and end by right harvesting period and logistic from the field to cooling chamber.

Key words: economic effectiveness, strawberry, sale, industrial market, freezing, marketing, enterprise, cooperatives.

\section{Ветуп}

Між більшістю виробників ягідної продукції, а особливо суниці побутує думка, що ринок переробки $\epsilon$ апріорі невигідним та туди можна здавати продукцію будь-якої якості, яка не продалася на свіжому ринку або є зіпсованою. Але слід пам'ятати, коли низька якість то і ціна не можу бути високою.

Справді, такий стереотип сформувався коли в поняття переробки ягідної продукції закладали тільки вичавлювання соку на концентрати або ж виробництво джемів та наповнювачів. Часто якість кінцевого продукту не була високою, відповідно і до сировини вимоги були відповідні.

В сучасних умовах плодово-ягідного ринку, велику популярність набуває заморожена продукція, яка після глибокої шокової заморозки може зберігатися до двох років не втрачаючи смакові властивості та корисності. Проте, такий спосіб переробки ягід вимагає якісної сировини, яка має відповідну консистенцію, лежкість, форму, запах, колір, а також буде придатною до миття та подальшої переробки. Окремим пунктом варто відзначити питання відсутності плодоніжки, за ягоду суниці садової без якісно видаленої плодоніжки переробник готовий платити значно більше. Щоб досягнути відповідного рівня видалення потрібно мати необхідні знання для керівного складу сільськогосподарських підприємств (агроном, бригадир), які в свою чергу мають їх передати збирачам ягоди. Аналіз економічної ефективності впровадження цих та інших підходів при збуті ягідної продукції і будуть проаналізовані нижче в статті.
Аналіз останніх досліджень і публікаиій. Питаннями теорії та практики ефективності сільськогосподарських підприємств загалом та плодово-ягідних зокрема займалися вітчизняні вчені-економісти О.Ю Срмаков, О.В. Кравець, В.В Лазня, Т.А. Маркіна, О.А. Полюхович, І.Н. Прімишев, В.А. Рульєв, O.M. Шестопаль, А.I. Шумейко та інші. Проблеми, пов'язані з адаптацією сільськогосподарських підприємств до умов ринку, досліджували В.I. Бойко, Ю.С. Коваленко, В.І. Криворучко, В.Я. МесельВеселяк, П.Т. Саблук, О.М. Шпичак, В.В. Юрчишин. Теоретичні, методичні та практичні аспекти розвитку, управління та регулювання господарської діяльності, формування експортного потенціалу підприємств України, в тому числі в сільськогосподарських, розглянуті у працях А. Альохіна, В. Авер'янова,

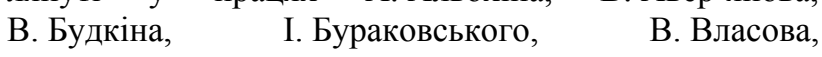
А. Гальчинського, В. Геєця, В. Горьового, В. Губенка, Б. Данилишина, С. Дем'яненка, Т. Зінчук, С. Кваші, О. Кириченка, Л. Михайлової, А. Мокія, О. Онищенка, М. Павловського, М. Портера, П. Саблука, О. Шпичака та інших вчених. Вище перелічені дослідження дуже важливі, однак вони недостатньо дають відповіді на виклики, які постають перед виробниками ягідник культур, зокрема суниці садової в теперішніх умовах. Так в їхніх роботах не в повній мірі розкривається потенціал ринку переробки ягідної продукції, як одного з перспективних та поки що мало розвинутого.

Метою статті є аналіз чинників, які впливають на підвищення ефективності збуту суниці садової в сільськогосподарських підприємствах та ОСГ на переро- 
бку. Також розглядатиметься роль сільськогосподарських обслуговуючих кооперативів (СОКів) в формуванні ланцюга збуту ягідної продукції для малих та середніх виробників.

\section{Результати та їх обговорення}

Плодово-ягідний напрямок сільського господарства України є надзвичайно важливим сегментом аграрної економіки. Окрім забезпечення споживачів свіжою продукцією, а виробників притоком фінансових ресурсів, він відіграє значну соціальну роль, яка полягає в припинення деградації та закладання основ для розвитку сільських територій. Це зумовлено тим, що ягідний напрямок вимагає великої кількості робочої сили, що не можна сказати скажімо про зерновий сектор. Так для прикладу для догляду за одним гектаром полуничних насаджень потрібно 5 осіб, а в сезон збору 10 - 12 осіб. Якщо врахувати, що середнє полуничне господарство має 3 га насаджень, то сукупна кількість зайнятих осіб становитиме 30-36 осіб, що є хорошим показником в умовах тотального безробіття в українському селі.

Ягідництво є також одним 3 найоптимальніших шляхів розвитку сільських родин, які мають в своїй власності земельні паї. Адже сільська родина - сімейна ферма маючи у власності від 1 до 3 га може успішно розвивати свій приватний бізнес заклавши плантацію ягід, для прикладу суниці садової. При середній врожайності 10 т/га., родина може отримати $200-$ 250 тис. грн. прибутку 3 одного гектара, таким чином покривши інвестиції в перший же рік плодоношення. Варто зазначити, що суниця є ягодою, яка забезпечує швидку оборотність коштів. Сподіваємось, що розвитку сімейного фермерства сприятиме і прийняття в 2016 році Закону України «Про внесення змін до Закону України «Про фермерське господарство» щодо стимулювання створення та діяльності сімейних фермерських господарств».

Переважно більшість сільськогосподарських підприємств та особливо ОСГ є зорієнтованими на збут ягід суниці на свіжий ринок, менше з них продають як на свіжому ринку так і на переробку. Звісно свіжий ринок є більш цікавим з точки зору ціни, якщо продукція є хорошої якості, правильно представлена, а на ринку немає перенасичення пропозиції. Проте, ринок суниці з року в рік $є$ різним і трапляються періоди перенасиченої пропозиції, коли ринок не може спожити великої кількості ягоди і тоді ціна свіжого ринку та переробки може вирівнятись. Тому для виробників суниці, особливо ті хто має від 1 га і більше варто цікавитись можливістю виходу на ринок переробки, особливо звертаючи увагу на заморозку. Він $є$ об'ємним, потреби настільки великі, що Україна на даний час власною продукцією закриває власні потреби тільки на 30 - 40\% своїх потреб. Інші 60\% імпортуються з Китаю, Польщі та інших країн.
Отже які основні переваги роботи з ринком переробки:

1. Гарантований збут;

2. Постачання великих об'ємів одному або декільком переробникам.

3. Економія часу, зусиль та коштів на збут ягоди через дрібний гурт;

4. Стабільна ціна як мінімум цілий сезон - за умови попереднього контрактування та виконання домовленостей;

5. Вихід на зовнішні ринки, заморожена ягода високої якості добре цінується;

6. Зростання ціни на полуницю через малі об'єми посадок протягом останніх 2015 - 2016 років.

Не вся суниця буде мати однакову вартість, оскільки переробні підприємства ставлять основною вимогою високу якість, відсутність плодоніжки та безпечність ягід. Для цього ягода повинна бути «консистентною, однорідною по степені стиглості, без стороннього запаху або присмаку, ягода ціла, чиста, суха, не перестигла, без плісняви, без механічних пошкоджень та пошкоджень шкідниками і хворобами.». Таке визначення ягоді суниці першого класу без плодоніжки дає компанія «Аграна Фрут», що у Вінниці.

Щоб забезпечити якісну ягоду сільськогосподарському виробнику необхідно виконати наступні кроки:

- використовувати відповідні сорти, які забезпечуватимуть лежкість та транспортабельність ягоди; вносити необхідні добрива в тій пропорції, кількості та в строки, рекомендовані технологією;

- вносити необхідні засоби захисту рослин для упередження появи шкідників та хвороб, які можуть пошкодити ягоду;

- збирати ягоду при $80-85 \%$ стиглості, не перестиглу;

- слідкувати щоб збирачі не м'яли, не кидали ягоду в ящик;

- плодоніжка має вичищатись так щоб не залишалось жодного іiї залишку на ягоді.

На Рисунках 1 та 2 показано приклади вірного та не вірного збору суниці без плодоніжки.

При прийомці на переробних підприємствах велика увага приймальників приділяється інспекції ягід, де детально оглядають кожну палету і шляхом вибірки встановлюють рівень вибраковки. При знаходженні невідповідних по якісних характеристиках ягід, а саме: гнилих, деформованих, брудних, пом'ятих, недостиглих, перестиглих відбувається процес вибракування, що позначається на кількості прийнятого товару від виробника. Якщо кількість невідповідної ягоди перевищує $6-8 \%$ (в залежності від підприємства), то палета або вся машина може бути зарахованою в другий клас або з плодоніжкою. На Рисунках 3 і 4 зображено вірний та не вірний рівень стиглості суниці для переробки на заморозку. 


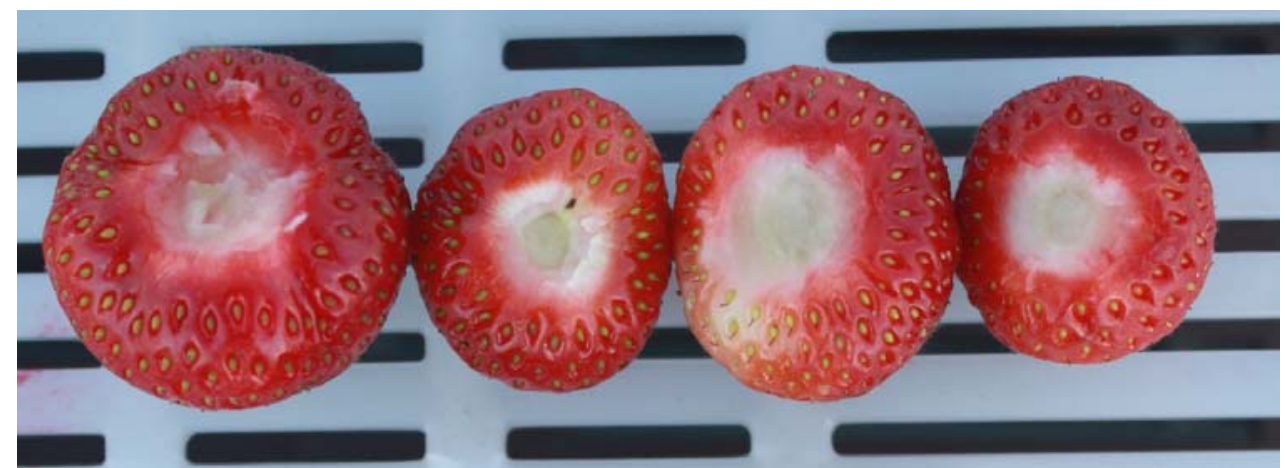

Рис. 1. Вірне очищення площа суниці від плодоніжки (Фото автора)

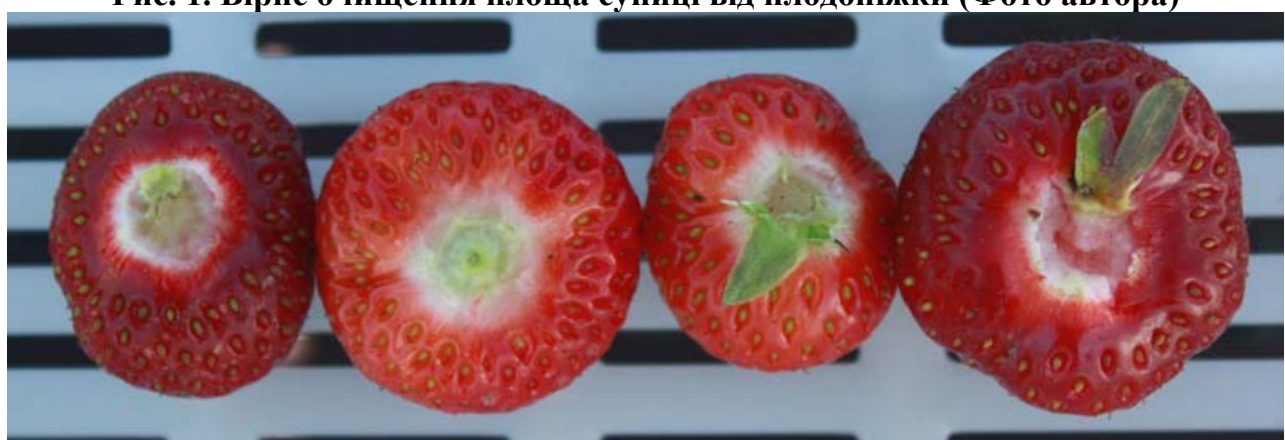

Рис. 2. Не вірне очищення площа суниці від плодоніжки (Фото автора)

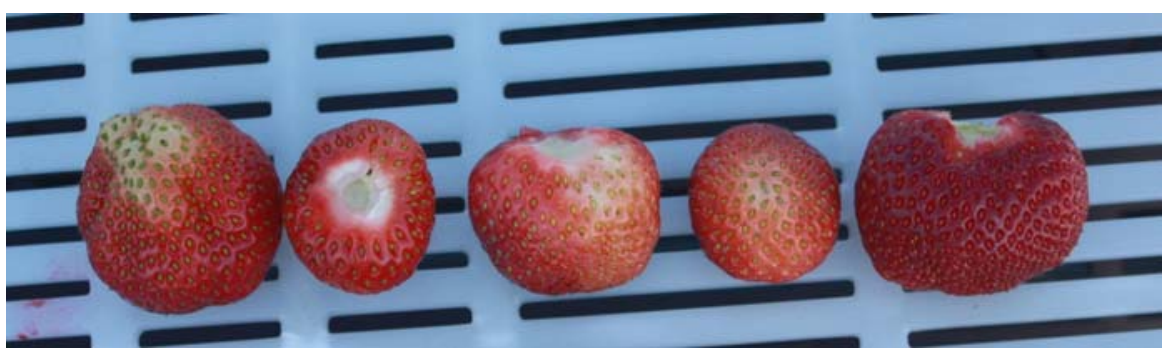

Рис. 3. Вірний рівень стиглості суниці на переробку

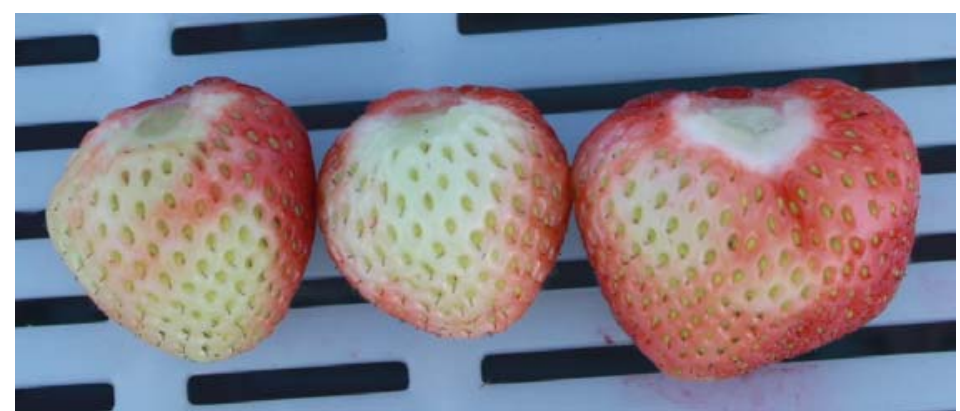

Рис. 4. Не вірний рівень стиглості суниці на переробку

Під час збору, суницю потрібно вивезти 3 поля протягом $2-3$ годин, бажано в камеру охолодження для приведення ііі до оптимальної температури та недопущення перегрівання на полі. Температурний режим в камері повинен становити $+4-8 \mathrm{C}$.

Логістику суниці необхідно проводити термоавтомобілем 3 холодильником 3 температурним режимом +4-6 С. В таких умовах ягода краще транспортується та ії можна переміщувати на віддаль до 300 км і більше.

Збут суниці на заморозку відбувається переважно на підприємства, які мають тунельну індивідуальну швидку заморозку (IQF) та здатні переробити за го- дину біля 5 т ягід. Температура в тунелі під час заморозки становить біля $-40 \mathrm{C}$.

Цінова політика на полуницю на переробку виглядає таким чином, що за ягоду без плодоніжки переважна більшість переробних підприємств платить на 3 грн/кг більше ніж 3 плодоніжкою. В свою чергу виробник збирачам платить за збір без плодоніжки на 0,5 $-1,00$ грн/кг дорожче. Отже економічний зиск очевидний і становить $2-2,5$ грн 3 кілограма.

Аналізуючи ціни та ринок суниці видно, що протягом 4 останніх років стабільно зберігається різниця між суницею з плодоніжкою та без неї. 
Табличя 1

Вартість суниці за типами

\begin{tabular}{|l|c|c|c|c|}
\hline & \multicolumn{4}{|c|}{ Вартість суниці, грн/кг без ПДВ } \\
\hline Тип суниці & 2013 & 2014 & 2015 & 2016 \\
\hline 3 плодоніжкою & 6,00 & 7,00 & 11,00 & 11,50 \\
\hline Без плодоніжки & 9,00 & 10,00 & 14,00 & 15,00 \\
\hline
\end{tabular}

Дані в Таблиці 1 базуються на власних дослідженнях автора протягом останніх чотирьох маркетингових років. Збір даних проходив у Львівській, Тернопільській, Волинській та Вінницькій областях шляхом опитування сільськогосподарських підприємств виробників суниці та переробників, які спеціалізуються на заготівлі ягід.

Таблиия 2

Вартість суниці на свіжому ринку та ринку переробки

\begin{tabular}{|l|c|c|c|c|}
\hline & \multicolumn{5}{|c|}{ Вартість суниці, грн/кг без } \\
\hline Тип ринку & 2013 & 2014 & 2015 & 2016 \\
\hline Свіжий ринок & 11,00 & 13,00 & 15,00 & 20 \\
\hline $\begin{array}{l}\text { Ринок переробки (суниця } \\
\text { без плодоніжки) }\end{array}$ & 9,00 & 10,00 & 14,00 & 15,00 \\
\hline
\end{tabular}

3 даних наведених в табл. 2 видно, що до 2016 року різниця у вартості суниці на свіжий ринок та на заморозку без плодоніжки не була кардинальною, що зумовлено порівняно великою кількістю пропозиції ягоди на ринку під час масового достигання. Слід врахувати, що ціна свіжого ринку подається з врахуванням пікового періоду збуту. Очевидно, що ранню та пізню суницю не має жодного сенсу здавати на переробку 3 огляду на цінову політику та неможливість формування великих партій. Починаючи з 2016 року, спостерігається подорожчання суниці на свіжому ринку, коли переробка не готова була так стрімко підвищувати ціну.

Причинами зростання ціни на 25\% є:

- $\quad$ загальне скорочення площ насаджень суниці садової через,

- переорієнтування уваги виробників на посадку малини, ціна на

яку в 2015 році була рекордною;

- $\quad$ не сприятливі погодні умови, а саме вкрай посушливе літо осінь 2015 року, декілька днів в грудні 2015p. 3 екстремально низькою температурою -2628C, а також квітневі заморозки весною 2016 року;

- $\quad$ девальвація гривні.

Особливу роль в збуті суниці садової можуть відігравати обслуговуючі кооперативи, які окрім ролі заготівельника та об'єднуючої ланки між виробником та переробником відіграють навчальну та просвітницьку роль. Вони мають доносити до виробників інформацію про нові технології, сорти, добрива та засоби захисту, методики підвищення врожайності та інше.

Наглядним прикладом є СОК в селі Лосятин Тернопільської області, який займається заготівлею та збутом не тільки суниці садової, а і малини. Маючи завдяки проекту міжнародної допомоги добре обладнану виробничу базу, яка включає в себе камеру охолодження на 40 тон та термо-автомобіль, кооператив заготовляє ягідну продукцію акумулюючи товарні партії, охолоджує іiі та власним автомобілем поставляє переробникам.

Також вже більше трьох років працює «ягідний» кооператив «Агрофрут» в Перемишлянському районі Львівської області. СОК активно розвивається, має необхідне навісне обладнання для надання послуг, залучає нових членів та проводить просвітницьку роботу щодо розвитку самозайнятості сільського населення, розбудови сімейних ферм та покращення їхнього добробуту.

\section{Висновки}

Успішне ведення господарської діяльності підприємствами та ОСГ, які вирощуються ягоди та зокрема суницю садову багато в чому залежить від вміння вигідно продати вирощену продукцію. Адже суниця має вкрай короткий строк зберігання та повинна бути проданою протягом доби після збору без охолодження та протягом двох діб за умов регульованої температури.

На даний час свіжий ринок викликає найбільший інтерес у виробників, оскільки ціна на ньому переважно є вищою ніж на ринку переробки. Проте, виробники не завжди правильно оцінюють можливості ринку переробки, яка може давати стабільну ціну та закупляти великі партії суниці, яку в піковий період важко продати на свіжому ринку. Так однією з можливостей $є$ робота з переробниками, які заморожують ягоду суниці та відповідно, платять преміальну ціну за товар без плодоніжки, але в той самий час $\epsilon$ вимогливими до якості.

Правильно налагодивши роботу з вирощування, збору та доробки ягід суниці на переробку, сільськогосподарські підприємства та ОСГ через кооперативи можуть розраховувати на хорошу ціну, а також зменшення затрат часу та коштів на пошук збуту тільки на свіжому ринку.

\section{Бібліографічні посилання}

Gubenko, V.I. (2013). Mehanizm zrostannja konkurentospromozhnosti tovariv APK na svi-tovomu rynku. Agroinkom. 1-2, 60-68 (in Ukrainian).

Kernasjuk, Ju.V. (2015). Ekonomichni perspektyvy vyroshhuvannja jagid. Ag-robiznes s'ogodni. 10(305), 20-22 (in Ukrainian).

Latynin, M.A. (2007). Derzhavne reguljuvannja agrarnogo sektora ekonomiky Ukrai'ny: av-toref. dys. na zdobuttja nauk. stupenja dok. ekon. nauk: spec. 25.00.02 «Mehanizmy derzhavnogo upravlinnja». Donec'k.

Ulanchuk, V.S., Anishhenko, G.Ju. (2011). Spozhyvchyj rynok plodojagidnoi' produkcii': stan ta perspektyvy rozvytku. Visnyk ekonomichnoi' nauky Ukrai'ny. 1, 158 (in Ukrainian).

Sabluka, P.T., Ambrosova, V.Ja., Mazneva, G.Je. (2001). Problemy efektyvnogo funkcionuvannja APK v umovah novyh form vlasnosti ta gospodarjuvannja: $U$ dvoh tomah. K.: IAE, 1, 831 (in Ukrainian).

Стаття надійшла до редакиії 10.10.2016 